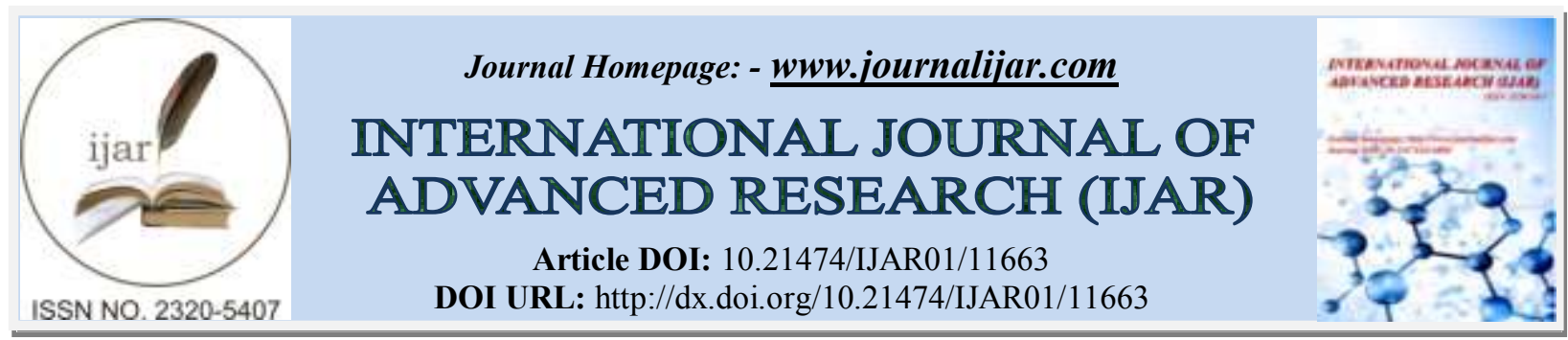

RESEARCH ARTICLE

\title{
AYURVEDA MANAGEMENT, ENSURING SAFE, EFFECTIVE NON-RECURRENT ACUTE DACRYOCYSTITIS - A CASE REPORT
}

\author{
Shantala Priyadarshini T.R ${ }^{1}$, Pannaga N. Teragundi ${ }^{2}$, Pooja S. ${ }^{2}$, Lavanya Sadanand ${ }^{2}$ and Priyanka ${ }^{2}$ \\ 1. Dean \&HOD, Department of Shalakya SIARAM.BhopalMadhya Pradesh, India. \\ 2. Ayurveda Consultant, Dr.Vijaya's Ayurveda Research \&Therapy Center, Jayanagar.
}

\section{Manuscript Info}

.........................

Manuscript History

Received: 10 July 2020

Final Accepted: 14 August 2020

Published: September 2020

Key words:-

Jaloukacharana, Puyalasaka, Bidalak, Acute Dacryocycstitis

\section{Abstract}

Two major conditions manifesting on the inner canthus are Puyalasaka and Upnaha," as enumerated in ancient treatises. Excessive lacrimation,swelling associated with pain and pus are the hallmarks of this condition. Patient seemingly healthy, aged around 60 years, not on any regular medication presented with symptoms of painful swelling filled with pus near the inner canthus of right eye. On mild pressure on the swollen lacrimal sac-regurgitation was noted -confirming acute dacryocystitis with nasolacrimal duct block.

Management:Jalaoukacharna after dehashudi and shirashudi was conducted. Followed by ,shoolashothaharabidalaka followed by prasadananjan was adopted. All symptoms mitigated. No scars or traces of nasolacrimal duct obstruction were seen.Ayurveda management done in this case promises non recurrence, is cost effective and has given fast results. Case followed for three years and acute or chronic manifestations have not manifested so it is significant and worth to be explored in large scale. Multi centric and various permutations and combinations for similar case are recommended for further research.

Copy Right, IJAR, 2020,. All rights reserved.

\section{Introduction:-}

Ayurveda's special branch termed 'Shalakya' denotes the unique and in separable proximity of the eyes, nose, ears and oral cavity. Anatomically, physiologically, pathologically and managerial interrelated factors are visualized. Acharya Susrutha describes the lacrimal ducts as Asruvahasrotas. ${ }^{(1)}$ Ayurveda.Acutedacryocystitis symptoms coincide with manifestations of Puyalasakaand chronic dacryocystitis could be correlated to upnaha :both sandhigatarogas. Ashruvahasrotos, (lacrimal duct)netrodaka (tears), ashruudavartha(blocking of nasolacrimal $d u c t$ )have been enumerated

Research articles written on Ayurveda management of dacryocystitisthrow light on various aspects worth looking into Ayurveda is preferred treatment due to failure of surgery, cost and complications followed after surgery. (2)(3)(4) Causes of failure of external dacryocystorhinostomy surgery have been listed as deviated septum, scar tissue, concha bullosa, septal adhesion, enlarged middle turbinate, and sump syndrome etc ${ }^{(5)(6)}$ Acute and chronic cases of dacryocystitis can be managed with Ayurveda alone and publishing it helps globally adopt this mange in similar cases. 


\section{Materials And Methods:-}

Case history

Patient aged 60 years lady, seeming healthy and not any regular medication. Epiphora from right eye, mild fever and headache since a week, developed painful pus filled swelling at the inner canthus of right eye since 2 days associated with decreased appetite and constipation. Darshan, sparshan and prashna pareeksha helped in diagnosis. Swelling on inner canthus of right eye, with pain and pus discharge on mild pressing on the lacrimal punctum confirmed the diagnosis.

Before treatment During with leech application After treatment
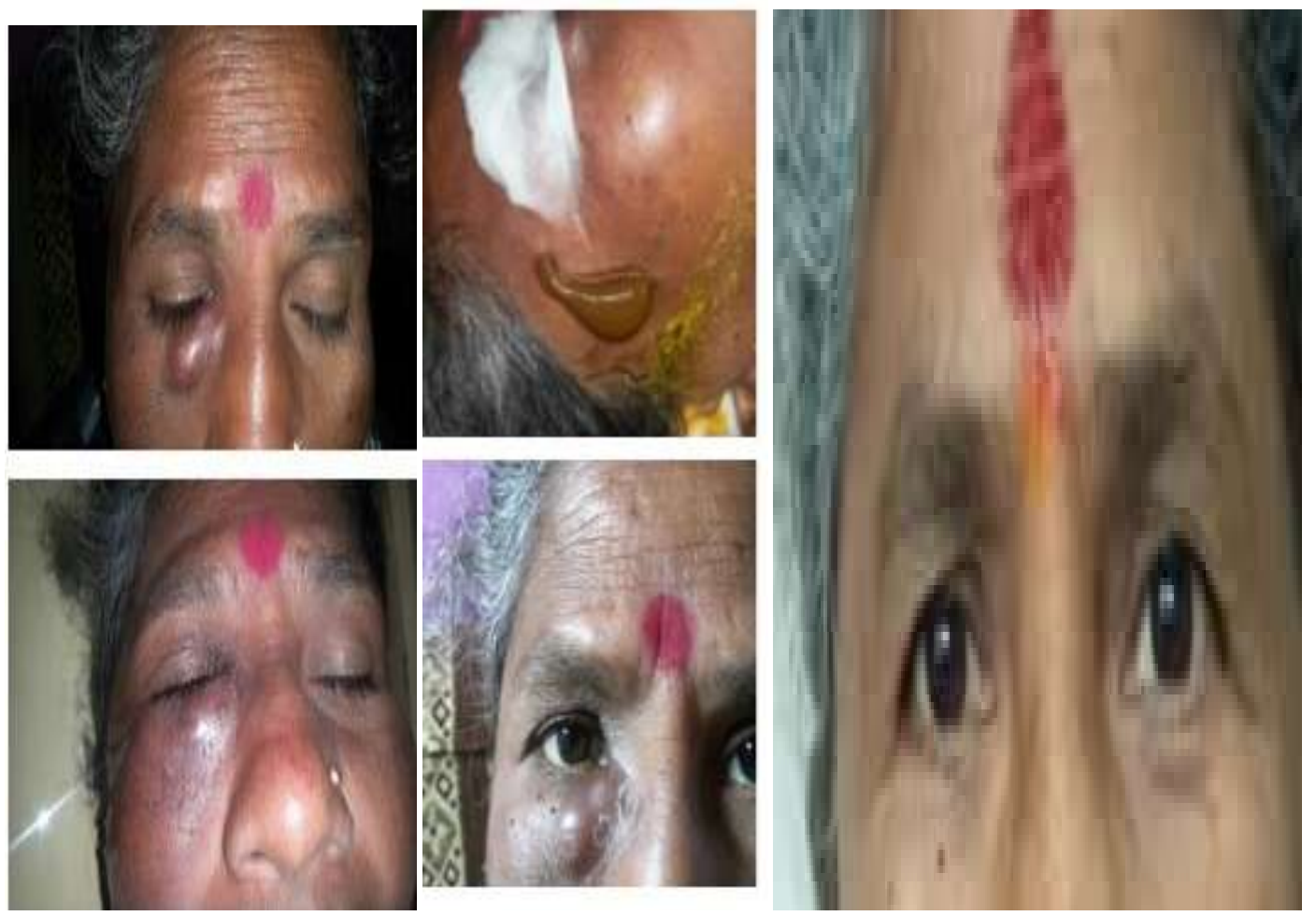

Darshan Pareeksha -red swelling in inner canthus of right eye. SparshanPstrrksha :pressure on lacrimal duct -pus and discharge seen. Prashnapareeksha :-manifestation of symptoms, medical and family historydetails were collected.Vision showed age related changes but all other sense organs did not report much to need medication. Management: line of treatment -agnideepana, kayashudi, shirashudi, raktamokshana, kriyakalpa was initially achieved by choushastiharpipalli 1/4 tea spoon mixed with honey administered thrice a day ${ }^{(7 . .}$ Erandasneha for achieving anulomana and kostashuddi. Anutaila for pratimarshanasya. ${ }^{(8)}$ Jalokacharna (JK) was done with all purva, pradhana and paschat karma as per shastra and it was uneventful, followed by bidalaka to mitigate pain and swelling. The parisheka was done using nalpamaradi kashyam done many times a day for a week. After pain and pus was totally under control prasadananjana was also adopted. The whole treatment was adopted as per rules and regulations so it was highly beneficial and no side effects at any stage occurred.

\begin{tabular}{|c|c|c|}
\hline Date & symptoms & Treatment \\
\hline 12.08 .17 & $\begin{array}{l}\text { Painful swelling with pus right eye - } \\
\text { inner canthus }+++++ \text { epiphora }\end{array}$ & $\begin{array}{l}\text { Sothashoola har bidalaka } \\
\text { Deepana - pachana C,pipali churna + honey }{ }^{(10)}\end{array}$ \\
\hline 15.08 .17 & Pain pus ++++ & Anuloman -erandasneha \\
\hline 16.08 .17 & Pain pus +++ & JK 20minutes -one leech \\
\hline 17.08 .17 & Pain pus + & Nalpamaradhiseka ,lekhanaanjana \\
\hline 20.08 .17 & Pain, swelling reduced & Nalpamaradhiseka +bidalaka \\
\hline 30.08 .17 & All symptoms reduced & Nalpamaradhiseka +bidalaka \\
\hline 15.09 .17 & No symptoms & Nalpamaradhiseka,prasadananjan \\
\hline 12.08 .19 & $6^{\text {th }}$ Follow up -no recurrence & Lacrimal system healthy \\
\hline
\end{tabular}

Table 01:- Treatment details 


\section{Results:-}

fast, effective and safety at all levels of treatment and no recurrence was noticed for three years. Management of acute stage of dacryocystitis was made possible adopting Ayurveda herbs and bloodletting using (JK)Jaloukacharana.

Follow up after 3years ---with no recurrence

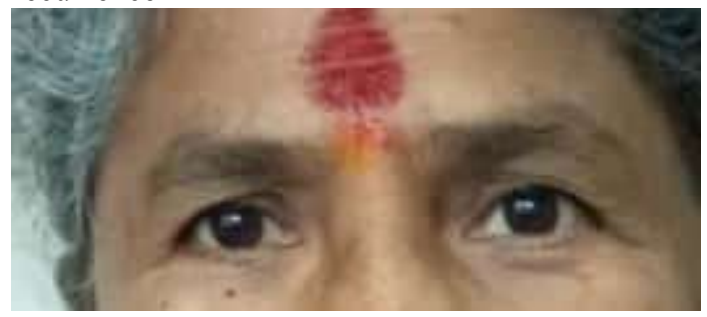

\section{Discussion:-}

Choushastiharpipalli also being chakshusya and rasayana gave multiple benefits. It is imperative to conduct such management so that patient benefits more at low cost, no hospitalization, no surgical intervention. Jaloukacharan adds benefits so that pain and inflammation can subside sooner without any antibiotics.Bidalakaapplication is herbal pastes applied on closed lids and it is absorbed much, giving immediate relief from all symptoms so also pariseka. All the ingredients utilized have been utilized in most common conditions and especially in eye diseases. Conclusion -treating acute and chronic dacryocystitiswithout any antibiotics or surgical intervention is worthy of taking note of and this needs to be taken in larger sample in multicenters to make it global,

\section{References:-}

1. Sushruta.Uttaratantra adyayal Acharya TrikamjiYadavji (Sushruta-Samhita with Nibandhasamgraha Commentary of Shree Dalhanacharya and Nyayachandrika commentary of Shree Gayadasacharya on Nidanasthana) Varanasi, India, ChaukhambhaSurbharati Prakashan,Reprint;2003;5 Sushruta. Sushruta Samhita with Nibandhsangraha Commentary of Dalhan. Uttar Tantra, 18/17-18. Varanasi: ChaukhambaSurbharti Publication; 2008; 634. 30.

2. Vagbhata. AsthangSamgrah with Sashilekha Commentary of Indu . Sutra Sthana, 33/1. Varanasi: Chaukhamba Sanskrit Series; 2006; 235.

3. Priyadarshini et al. World Journal of Pharmaceutical Research, Vol 6, Issue 3, 2017. P1133https://www.researchgate.net/publication/333772689_AYURVEDIC_MANAGEMENT_OF_DACRYO CYSTITIS TO PREVENT_SURGICAL_INTERVENTION

4. Kharavartiprayoga (Akali thread)in puyalasa (Acute Dacryocystitis) :A Case report.Journal of Ayurveda Integrated Medical Sceinces Mar April 2019,Vol 4,Issue 2,95--98

5. Rathod et al. ejbps, 2018, Volume 5, Issue 3, 708-710. Case Report S ROLE OF AYURVEDIC TREATMENT MODALITIES IN THE MANAGEMENT OF KAPHAJA SRAVA WITH SPECIAL REFERENCE TO EPIPHORA- A CASE REPORT

6. Ghasemi, H., AsghariAsl, S., Yarmohammadi, M. E., Jafari, F., \& Izadi, P. (2017). External Dacryocystorhinostomy; Success Rate and Causes of Failure in Endoscopic and Pathologic Evaluations. Iranian journal of pathology, 12(3), 189-194.

7. Lin GC, Brook CD, Hatton MP, Metson R. Causes of dacryocystorhinostomy failure: External versus endoscopic approach. Am J Rhinol Allergy. 2017;31(3):181-185. doi:10.2500/ajra.2017.31.4425

8. Ambili KP, Ranjini KC. Success rate comparison of external Dacryocystorhinostomy with and without silicone intubation for the treatment of primary nasolacrimal duct obstruction. Journal of Evidence based Medicine and Healthcare; August 03, 2015; 2(31): Page: 4508-4517, DOI: 10.18410/jebmh/2015/636.

9. Raju Thomas,Hasmuk h,Jadhav,Prajapati.P.K.Standard manufacturing procedure of Chatuh shasti -Prahari pipalli churna prepared by different methods .Int.Res Ayurveda Pharm.2014:5(3)266-269. 